\title{
Seroprevalence and Risk Factors Associated with Chlamydia abortus Infection in Sheep and Goats in Eastern Saudi Arabia
}

\author{
Mahmoud Fayez ${ }^{1,2,+}+\mathbb{D}$, Ahmed Elmoslemany ${ }^{3,+}\left(\mathbb{D}\right.$, Mohammed Alorabi ${ }^{4}$, Mohamed Alkafafy ${ }^{4}$, \\ Ibrahim Qasim ${ }^{5}$, Theeb Al-Marri ${ }^{1}$ and Ibrahim Elsohaby $6,7, *,+\mathbb{D}$
}

1 Al-Ahsa Veterinary Diagnostic Lab, Ministry of Environment, Water and Agriculture, Al-Ahsa 31982, Saudi Arabia; mahmoudfayez30@hotmail.com (M.F.); theep8@hotmail.com (T.A.-M.)

2 Department of Bacteriology, Veterinary Serum and Vaccine Research Institute, Ministry of Agriculture, Cairo 131, Egypt

3 Hygiene and Preventive Medicine Department, Faculty of Veterinary Medicine, Kafrelsheikh University, Kafr El-Sheikh 33516, Egypt; aelmoslemany@gmail.com

4 Department of Biotechnology, College of Science, Taif University, P.O. Box 11099, Taif 21944, Saudi Arabia; maorabi@tu.edu.sa (M.A.); m.kafafy@tu.edu.sa (M.A.)

5 Department of Animal Resources, Ministry of Environment, Water and Agriculture, Riyadh 12629, Saudi Arabia; i.qasim@mewa.gov.sa

6 Department of Animal Medicine, Faculty of Veterinary Medicine, Zagazig University, Zagazig City 44511, Egypt

7 Department of Health Management, Atlantic Veterinary College, University of Prince Edward Island, Charlottetown, PE C1A 4P3, Canada

* Correspondence: ielsohaby@upei.ca; Tel.: +1-902-566-6063

+ These authors contributed equally to this work.

Citation: Fayez, M.; Elmoslemany, A.; Alorabi, M.; Alkafafy, M.; Qasim, I.; Al-Marri, T.; Elsohaby, I.

Seroprevalence and Risk Factors Associated with Chlamydia abortus Infection in Sheep and Goats in Eastern Saudi Arabia. Pathogens 2021, 10, 489. https://doi.org/10.3390/ pathogens10040489

Academic Editor: Martina Jelocnik

Received: 16 March 2021

Accepted: 12 April 2021

Published: 17 April 2021

Publisher's Note: MDPI stays neutral with regard to jurisdictional claims in published maps and institutional affiliations.

Copyright: (c) 2021 by the authors. Licensee MDPI, Basel, Switzerland. This article is an open access article distributed under the terms and conditions of the Creative Commons Attribution (CC BY) license (https:/ / creativecommons.org/licenses/by/ $4.0 /)$.
Abstract: Chlamydia abortus (C. abortus) is intracellular, Gram-negative bacterium that cause enzootic abortion in sheep and goats. Information on C. abortus seroprevalence and flock management risk factors associated with C. abortus seropositivity in sheep and goats in Saudi Arabia are scarce. The objectives of this study were to (i) estimate the animal, flock, and within-flock seroprevalence of C. abortus among Eastern Province sheep and goat flocks and (ii) identify the flock management and animal risk factors associated with C. abortus seropositivity in Eastern Province, Saudi Arabia. A crosssectional study with a two-stage sampling process was carried out in the Eastern Province, Saudi Arabia, between 2015 and 2016. A total of 1717 sheep and 1101 goat serum samples were collected from 21 sheep and 14 goat flocks, then were tested for C. abortus antibodies using a commercial ELISA Kit. In addition, vaginal swabs and aborted tissue samples were collected from sheep $(n=48)$ and goats $(\mathrm{n}=15)$ with recent history of abortion for detection of C. abortus pmp gene using PCR. A questionnaire was constructed to collect information about flock management and animal risk factors possibly associated with C. abortus infection in sheep and goats. The true sheep and goatlevel seroprevalences were 11.1\% (95\% CI: 9.7-12.7) and 10.6\% (95\% CI: 8.8-12.5), respectively. The true flock-level seroprevalence was $100 \%$ for both sheep and goats. However, the average within sheep and goat flocks true seroprevalences were 9.6\% (95\% CI: 1.8-22.9) and 9.3\% (95\% CI: 1.8-19.5), respectively. Multivariable logistic regression revealed that introduction of new sheep to the flocks $(\mathrm{OR}=2.6 ; 95 \% \mathrm{CI}: 1.5-4.4)$, type of breeding system (OR $=1.8 ; 95 \% \mathrm{CI}: 1.0-3.4)$, flocks allowing females in (OR $=1.9 ; 95 \%$ CI: $1.1-3.3)$ or females out (OR $=2.2 ; 95 \%$ CI: $1.1-4.3)$, and sheep age 1.4-2.8 years ( $\mathrm{OR}=1.9 ; 95 \% \mathrm{CI}$ : $1.3-2.9)$ were potential risk factors for $C$. abortus seropositivity in sheep flocks. However, in goat flocks, the introduction of new goats to the flocks (OR: 1.9; 95\% CI: 1.2-3.0) was identified as a risk factor, whereas good farm hygiene (OR: 0.3; 95\% CI: 0.2-0.7) was identified as a protective factor. C. abortus pmp gene was identified in $45(93.8 \%)$ and $15(100 \%)$ of samples collected from sheep and goats, respectively. These results could be used to implement efficient management measures to prevent and control C. abortus infection in sheep and goats in Eastern Province, Saudi Arabia, but also could be used to reduce the risk of C. abortus infection in sheep and goat flocks with similar management practices in other regions. 
Keywords: Chlamydia abortus; seroprevalence; risk factors; multivariable analysis; sheep; goats; Saudi Arabia

\section{Introduction}

Chlamydia is an obligate intracellular, Gram-negative bacterium that causes various diseases in animals and humans [1,2]. However, Chlamydia abortus (C. abortus) and Chlamydia pecorum (C. pecorum) are the two Chlamydia species that cause serious infection in sheep and goats [3,4]. C. abortus is one of the main causes of abortion in sheep and goats worldwide [5,6] and usually transmitted through ingestion or inhalation of dust, food, and / or water contaminated with aborted animal uterine discharge, placenta, and fetus [3,7]. C. abortus cause enzootic abortion disease in sheep and goats which characterized clinically by abortion in the last $2-3$ weeks of pregnancy [3]. Furthermore, C. abortus infection may cause stillbirth, premature lambing, and delivery of weak lamb/kids that generally die immediately $[3,8]$. In human, C. abortus infection is considered a zoonotic occupational disease and most of the infections were reported in veterinarians, livestock breeders, butchers, abattoir, and farm workers [3,9]. In humans, common symptoms in men and women are characterized by mild influenza-like illness or urethritis, however in severe cases, pregnant women are also at risk of abortion [10-13].

Several studies have investigated the seroprevalence of C. abortus in sheep and goats [14-16]. However, limited studies have assessed the flock-level risk factors associated with C. abortus seropositivity in sheep and goat flocks, including flock size, reproductive practices, husbandry, and farm sanitation [17-19]. Previous studies have reported that the real drivers of C. abortus infection in sheep [16,17], goats [19,20], camels [21], and cattle [22] are intrinsic farm factors such as production system and management practices, but a clearer understanding of these factors is needed. Knowledge of flock management practices and factors associated with the risk of $C$. abortus infection would prevent transmission and improve control strategies. In addition to the quality and effectiveness of the C. abortus diagnostic tests, C. abortus diagnosis requires either detection of bacteria/antigen by microscopic, immunofluorescence, ELISA, detection of the bacterial DNA by PCR and microarray [23,24], or detection of antibodies against $C$. abortus by ELISA [24,25].

In Saudi Arabia, few seroprevalence surveys have been conducted across different ruminants, including camels [26,27], sheep, and goats [28]. However, data on farm management risk factors for C. abortus infection in sheep and goats in Saudi Arabia is limited. Determination of $C$. abortus seroprevalence and risk factors associated with infection could help in the control of C. abortus in both animals and humans in Saudi Arabia. Therefore, the objectives of the present study were to (i) estimate the animal, flock, and within-flock seroprevalence of C. abortus among sheep and goat flocks in Eastern Province and (ii) identify the flock management and animal risk factors associated with $C$. abortus seroprevalence among sheep and goat flocks in Eastern Province, Saudi Arabia.

\section{Results}

\subsection{Seroprevalence Animal- and Flock-Level}

Out of the 1717 sheep tested in the present study, 187 were seropositive to C. abortus with apparent individual sheep-level seroprevalence of $10.9 \%$ (95\% CI: 9.5-12.5). At the flock-level, all 21 sheep flocks had at least one C. abortus seropositive sheep, giving an apparent sheep flock-level seroprevalence of $100 \%$. However, the average of within-flock seroprevalence was $9.4 \%$ and ranged from $1.7 \%$ to $22.5 \%$ (Figure 1 ). 


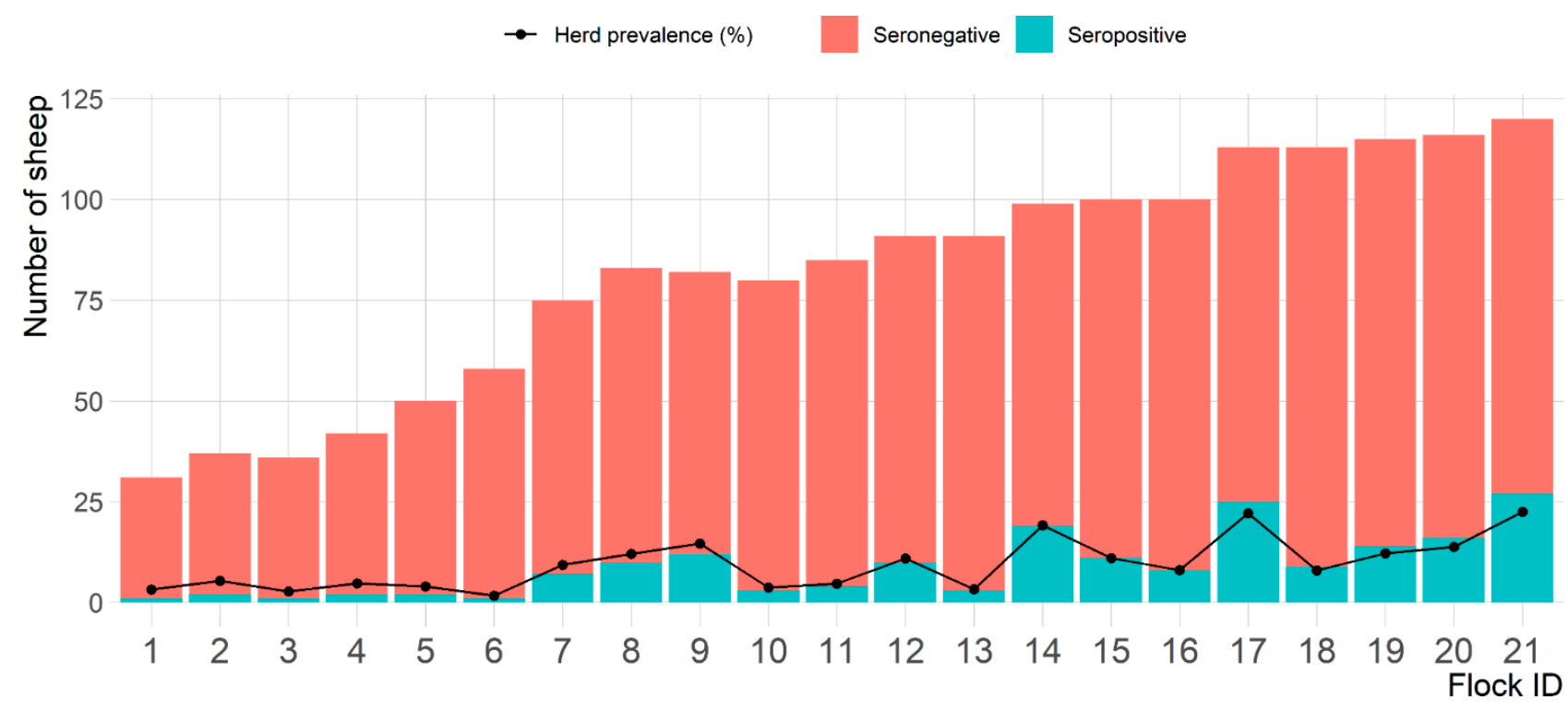

Figure 1. Number of seropositive and seronegative sheep and percentage of Chlamydia abortus seropositive sheep per flock on 21 sheep flocks in Eastern Province, Saudi Arabia.

For goats, 114 were seropositive to C. abortus out of 1101 goats tested, with an apparent seroprevalence on the goat-level of $10.4 \%$ (95\% CI: 8.6-12.3). Whereas at the flock level, all 14 goat flocks had at least one goat seropositive to C. abortus with an apparent goat flock-level seroprevalence of $100 \%$ and the average of within-flock seroprevalence of $9.1 \%$ and ranged from $1.7 \%$ to $19.1 \%$ (Figure 2).

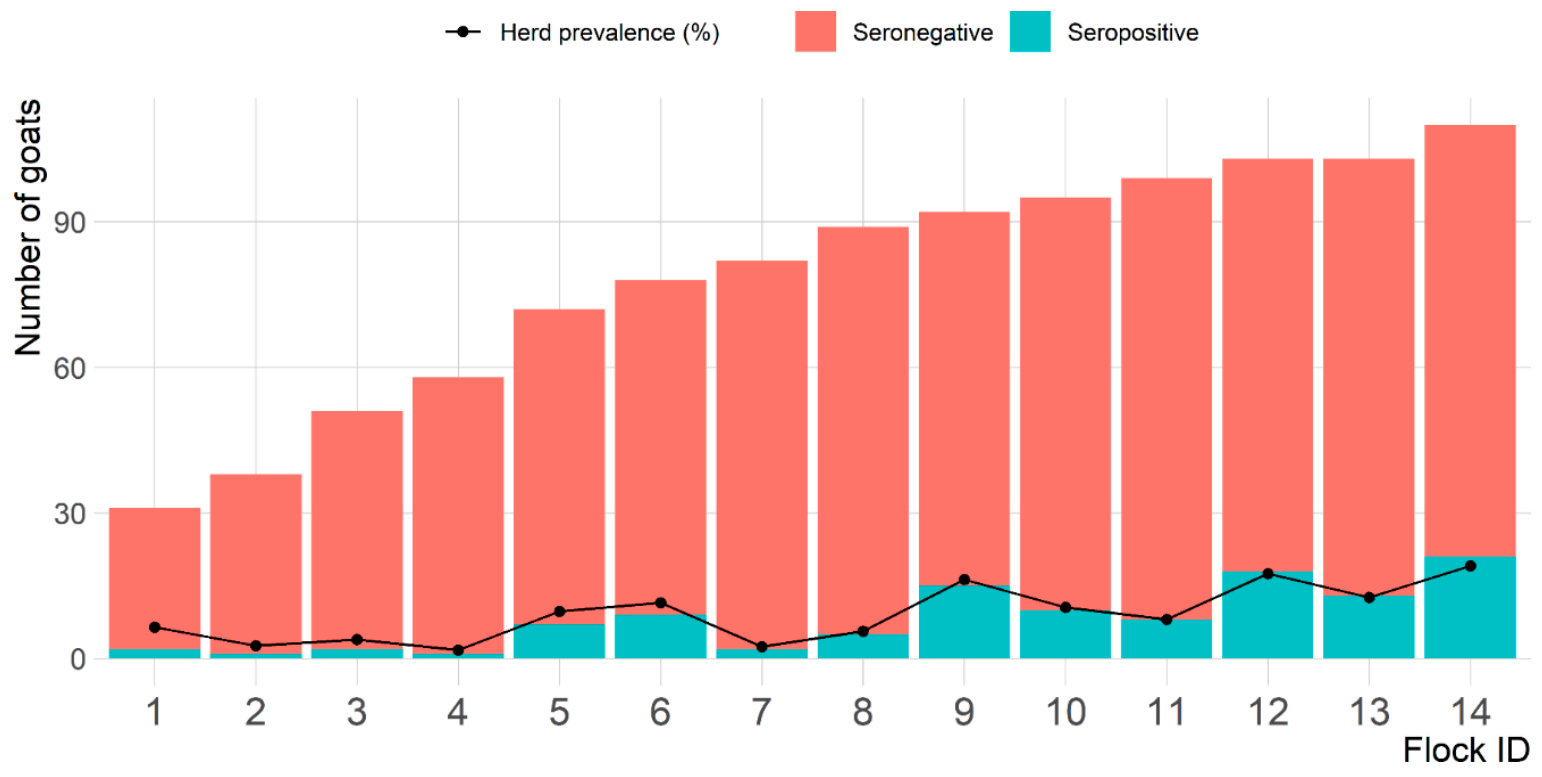

Figure 2. Number of seropositive and seronegative goats and percentage of Chlamydia abortus seropositive goats per flock on 14 goat flocks in Eastern Province, Saudi Arabia.

The apparent animal, flock, and within-flock seroprevalences were adjusted to the ELISA test Se (98.1\%) and Sp (100\%). Thus, the true sheep and goat-level seroprevalences were $11.1 \%$ (95\% CI: 9.7-12.7) and 10.6\% (95\% CI: 8.8-12.5), respectively. For both sheep and goats, the true flock-level seroprevalence was $100 \%$, with an overall HSe and HSp were equal to 1.00 and 1.00, respectively. The average within sheep and goat flocks true seroprevalence were $9.58 \%$ (95\% CI: 1.8-22.9) and 9.3 (95\% CI: 1.8-19.5), respectively. 


\subsection{Risk Factor Analysis}

The flock and animal risk factors associated with sheep and goats seropositivity in a univariable analysis at $P<0.20$ are presented in Tables 1 and 2, respectively. In sheep flocks, results showed a significant positive association (risk factor) between $C$. abortus seropositivity and larger flock size $(P=0.075)$, season $(P=0.003)$, recent history of abortion $(P=0.000)$, the introduction of new sheep to flock $(P=0.000)$, history of previous treatment ( $P=0.001)$, type of breeding system $(P=0.000)$, sheep exchange during breeding $(P=0.007)$, and sheep age $(P=0.003)$. Whereas, farm hygiene $(P=0.002)$ was negatively associated (protective factors) with C. abortus seropositivity (Table 1). Similar results were found in goat flocks, except recent history of abortion $(P=0.969)$, the history of previous treatment $(P=0.654)$, and type of breeding system $(P=0.855)$ were not significantly associated with C. abortus seropositivity (Table 2).

Table 1. Univariable analysis of flock and animal risk factors association $(P<0.20)$ with Chlamydia abortus seropositivity among sheep sampled from 21 flocks in Eastern Province, Saudi Arabia.

\begin{tabular}{|c|c|c|c|c|}
\hline Factors & $\begin{array}{c}\text { Frequency of } \\
\text { Examined Sheep (\%) }\end{array}$ & $\begin{array}{c}\text { Prevalence of } \\
\text { Seropositive Sheep (\%) }\end{array}$ & OR $(95 \% \mathrm{CI})^{1}$ & $P$-Value \\
\hline \multicolumn{5}{|c|}{ Flock Level } \\
\hline \multicolumn{5}{|l|}{ Flock size } \\
\hline Small $(\leq 200)$ & 28.8 & 7.7 & 1.0 (ref.) & \\
\hline Large $(>200)$ & 71.2 & 12.2 & $1.8(0.9-3.4)$ & 0.075 \\
\hline \multicolumn{5}{|l|}{ Season } \\
\hline Summer & 18.7 & 6.5 & 1.0 (ref.) & 0.003 \\
\hline Winter & 41.4 & 15.0 & $2.7(1.3-5.5)$ & 0.006 \\
\hline Spring & 23.3 & 11.3 & $1.8(0.8-3.9)$ & 0.131 \\
\hline Autumn & 16.6 & 5.3 & $0.8(0.3-2.1)$ & 0.710 \\
\hline \multicolumn{5}{|c|}{ Recent history of abortion } \\
\hline No & 85.6 & 6.9 & 1.0 (ref.) & \\
\hline Yes & 14.4 & 34.8 & $308.3(91.0-1030.6)$ & 0.000 \\
\hline \multicolumn{5}{|c|}{ Introductions of new sheep to the flock } \\
\hline No & 61.4 & 7.1 & 1.0 (ref.) & \\
\hline Yes & 38.6 & 16.9 & $2.7(1.8-4.2)$ & 0.000 \\
\hline \multicolumn{5}{|l|}{ Mixed breeding farm } \\
\hline No & 82.8 & 11.1 & 1.0 (ref.) & \\
\hline Yes & 17.2 & 10.1 & $1.2(0.5-2.8)$ & 0.713 \\
\hline \multicolumn{5}{|l|}{ Farm hygiene } \\
\hline Bad & 85.9 & 12.1 & 1.0 (ref.) & \\
\hline Good & 14.1 & 3.3 & $0.3(0.1-0.6)$ & 0.002 \\
\hline \multicolumn{5}{|c|}{ History of previous treatment } \\
\hline No & 85.5 & 10.0 & 1.0 (ref.) & \\
\hline Yes & 14.5 & 16.1 & $1.9(1.3-2.9)$ & 0.001 \\
\hline \multicolumn{5}{|c|}{ Type of breeding system } \\
\hline Closed & 49.5 & 6.9 & 1.0 (ref.) & \\
\hline Open & 50.5 & 14.8 & $2.5(1.5-4.0)$ & 0.000 \\
\hline \multicolumn{5}{|c|}{ Sheep exchange during breeding } \\
\hline No & 33.0 & 6.4 & 1.0 (ref.) & 0.007 \\
\hline Female out & 17.2 & 10.9 & $2.2(1.0-5.0)$ & 0.055 \\
\hline Female in & 49.8 & 13.9 & $2.7(1.4-5.0)$ & 0.002 \\
\hline \multicolumn{5}{|l|}{ Vaccine type } \\
\hline Clostridia (C) only & 14.0 & 8.3 & 1.0 (ref.) & 0.523 \\
\hline Pasteurella (P) only & 9.2 & 5.7 & $0.6(0.2-2.4)$ & 0.494 \\
\hline $\mathrm{C}+\mathrm{P}$ & 34.3 & 12.1 & $1.4(0.5-3.6)$ & 0.500 \\
\hline $\mathrm{C}+\mathrm{P}+\mathrm{PPR}$ & 42.5 & 11.9 & $1.4(0.6-3.4)$ & 0.501 \\
\hline
\end{tabular}


Table 1. Cont.

\begin{tabular}{|c|c|c|c|c|}
\hline Factors & $\begin{array}{c}\text { Frequency of } \\
\text { Examined Sheep (\%) }\end{array}$ & $\begin{array}{c}\text { Prevalence of } \\
\text { Seropositive Sheep (\%) }\end{array}$ & OR $(95 \% \text { CI })^{1}$ & $P$-Value \\
\hline \multicolumn{5}{|c|}{ Animal level } \\
\hline \multicolumn{5}{|l|}{ Age } \\
\hline$<1.4$ year & 26.1 & 7.2 & 1.0 (ref.) & 0.003 \\
\hline $1.4-2.8$ years & 51.0 & 13.4 & $2.0(1.3-3.0)$ & 0.002 \\
\hline$\geq 2.8$ years & 22.9 & 9.7 & $1.3(0.8-2.2)$ & 0.267 \\
\hline \multicolumn{5}{|l|}{ Sex } \\
\hline Male & 7.4 & 12.6 & 1.0 (ref.) & \\
\hline Female & 92.6 & 10.8 & $0.8(0.5-1.5)$ & 0.506 \\
\hline \multicolumn{5}{|l|}{ Breed } \\
\hline Awassi (Naeimi) & 40.1 & 12.5 & 1.0 (ref.) & 0.352 \\
\hline Najdi & 26.3 & 9.1 & $0.7(0.4-1.5)$ & 0.421 \\
\hline Sawakin & 10.5 & 6.2 & $0.5(0.2-1.4)$ & 0.182 \\
\hline Mixed & 23.1 & 12.4 & $1.2(0.6-2.7)$ & 0.598 \\
\hline
\end{tabular}

${ }^{1}$ OR: odds ratio; CI: confidence interval.

Table 2. Univariable analysis of flock and animal risk factors association $(P<0.20)$ with Chlamydia abortus seropositivity among goats sampled from 14 flocks in Eastern Province, Saudi Arabia.

\begin{tabular}{|c|c|c|c|c|}
\hline Factors & $\begin{array}{c}\text { Frequency of } \\
\text { Examined Goats }(\%)\end{array}$ & $\begin{array}{c}\text { Prevalence of } \\
\text { Seropositive Goats (\%) }\end{array}$ & OR $(95 \% \mathrm{CI})^{1}$ & $P$-Value \\
\hline \multicolumn{5}{|c|}{ Flock Level } \\
\hline \multicolumn{5}{|l|}{ Flock size } \\
\hline Small $(\leq 200)$ & 29.8 & 6.7 & 1.0 (ref.) & \\
\hline Large $(>200)$ & 70.2 & 11.9 & $2.0(1.0-4.0)$ & 0.067 \\
\hline \multicolumn{5}{|l|}{ Season } \\
\hline Summer & 12.7 & 2.1 & 1.0 (ref.) & 0.038 \\
\hline Winter & 47.6 & 12.2 & $6.2(1.7-22.4)$ & 0.005 \\
\hline Spring & 21.4 & 12.3 & $6.0(1.6-23.1)$ & 0.009 \\
\hline Autumn & 18.3 & 9.0 & $4.5(1.1-17.4)$ & 0.032 \\
\hline \multicolumn{5}{|c|}{ Recent history of abortion } \\
\hline No & 97.7 & 8.2 & 1.0 (ref.) & \\
\hline Yes & 2.3 & 100 & 644.7 & 0.969 \\
\hline \multicolumn{5}{|c|}{ Introductions of new goats to the flock } \\
\hline No & 80.7 & 8.5 & 1.0 (ref.) & \\
\hline Yes & 19.4 & 18.3 & $2.6(1.4-5.0)$ & 0.004 \\
\hline \multicolumn{5}{|c|}{ Mixed breeding farm } \\
\hline No & 74.3 & 11.1 & 1.0 (ref.) & \\
\hline Yes & 25.7 & 8.1 & $0.8(0.4-2.0)$ & 0.692 \\
\hline \multicolumn{5}{|l|}{ Farm hygiene } \\
\hline Bad & 69.9 & 12.9 & 1.0 (ref.) & \\
\hline Good & 30.2 & 4.5 & $0.3(0.2-0.6)$ & 0.000 \\
\hline \multicolumn{5}{|c|}{ History of previous treatment } \\
\hline No & 97.2 & 10.5 & 1.0 (ref.) & \\
\hline Yes & 2.8 & 6.5 & $0.7(0.1-4.1)$ & 0.654 \\
\hline \multicolumn{5}{|c|}{ Type of breeding system } \\
\hline Closed & 91.0 & 10.6 & 1.0 (ref.) & \\
\hline Open & 9.0 & 8.1 & $0.9(0.2-3.4)$ & 0.855 \\
\hline \multicolumn{5}{|c|}{ Goat exchange during breeding } \\
\hline No & 38.3 & 4.8 & 1.0 (ref.) & \\
\hline Female out & 26.3 & 14.8 & $3.5(2.0-6.3)$ & 0.000 \\
\hline Female in & 35.4 & 13.1 & $3.0(1.7-5.3)$ & 0.000 \\
\hline
\end{tabular}


Table 2. Cont

\begin{tabular}{|c|c|c|c|c|}
\hline Factors & $\begin{array}{c}\text { Frequency of } \\
\text { Examined Goats }(\%)\end{array}$ & $\begin{array}{c}\text { Prevalence of } \\
\text { Seropositive Goats }(\%)\end{array}$ & OR $(95 \% \mathrm{CI})^{1}$ & $P$-Value \\
\hline \multicolumn{5}{|c|}{ Goat exchange during breeding } \\
\hline No & 38.3 & 4.8 & 1.0 (ref.) & \\
\hline Female out & 26.3 & 14.8 & $3.5(2.0-6.3)$ & 0.000 \\
\hline Female in & 35.4 & 13.1 & $3.0(1.7-5.3)$ & 0.000 \\
\hline \multicolumn{5}{|l|}{ Vaccine type } \\
\hline Clostridia (C) only & 12.1 & 3.0 & 1.0 (ref.) & 0.109 \\
\hline Pasteurella (P) only & 9.0 & 8.1 & $2.9(0.6-13.1)$ & 0.175 \\
\hline $\mathrm{C}+\mathrm{P}$ & 14.9 & 13.4 & $4.9(1.3-18.4)$ & 0.017 \\
\hline $\mathrm{C}+\mathrm{P}+\mathrm{PPR}$ & 64.0 & 11.4 & $3.8(1.2-12.3)$ & 0.028 \\
\hline \multicolumn{5}{|c|}{ Animal level } \\
\hline \multicolumn{5}{|l|}{ Age } \\
\hline$\leq 2$ year & 51.2 & 9.2 & 1.0 (ref.) & \\
\hline$>2$ year & 48.8 & 11.6 & $1.4(0.9-2.0)$ & 0.121 \\
\hline \multicolumn{5}{|l|}{ Sex } \\
\hline Male & 16.0 & 10.3 & 1.0 (ref.) & \\
\hline Female & 84.0 & 10.8 & $1.0(0.6-0.6)$ & 0.879 \\
\hline \multicolumn{5}{|l|}{ Breed } \\
\hline Aradi & 41.7 & 13.1 & 1.0 (ref.) & 0.255 \\
\hline Damascus & 27.3 & 10.0 & $0.7(0.3-1.5)$ & 0.367 \\
\hline Mixed & 31.0 & 7.0 & $0.5(0.2-1.1)$ & 0.105 \\
\hline
\end{tabular}

${ }^{1}$ OR: odds ratio; CI: confidence interval.

Table 3 showed flock and animal level factors associated with sheep and goats seropositivity in a multivariable analysis at $P<0.05$. In both sheep and goat populations, the flock size variable could be a potential confounder based on the change in the $\beta$-coefficient $(>20 \%)$. Flock size was kept as a continuous variable in the sheep model, given that assumption of linearity was respected. However, this variable was kept as a categorized variable in the goat model, given linearity was not respected.

Table 3. Multivariable logistic regression analysis of flock and animal risk factors association $(P<0.05)$ with Chlamydia abortus seropositivity among sheep and goats sampled from flocks in Eastern Province, Saudi Arabia.

\begin{tabular}{|c|c|c|}
\hline Factors & OR $(95 \% \mathrm{CI})^{1}$ & P-Value \\
\hline \multicolumn{3}{|c|}{ Sheep } \\
\hline Flock size (continuous) & $0.99(0.99-1.0)$ & 0.146 \\
\hline \multicolumn{3}{|c|}{ Introductions of new sheep to the flock } \\
\hline No & 1.0 (ref.) & \\
\hline Yes & $2.6(1.5-4.4)$ & 0.001 \\
\hline \multicolumn{3}{|l|}{ Type of breeding system } \\
\hline Closed & 1.0 (ref.) & \\
\hline Open & $1.8(1.0-3.4)$ & 0.056 \\
\hline \multicolumn{3}{|c|}{ Sheep exchange during breeding } \\
\hline No & 1.0 (ref.) & 0.041 \\
\hline Female out & $2.2(1.1-4.3)$ & 0.026 \\
\hline Female in & $1.9(1.1-3.3)$ & 0.020 \\
\hline \multicolumn{3}{|l|}{ Age } \\
\hline$<1.4$ years & 1.0 (ref.) & 0.004 \\
\hline $1.4-2.8$ years & $1.9(1.3-2.9)$ & 0.022 \\
\hline$\geq 2.8$ years & $1.3(0.8-2.1)$ & 0.313 \\
\hline
\end{tabular}


Table 3. Cont.

\begin{tabular}{lcc}
\hline \multicolumn{1}{c}{ Factors } & OR $\left(\mathbf{9 5} \%\right.$ CI) ${ }^{\mathbf{1}}$ & P-Value \\
\hline & Goats & \\
\hline $\begin{array}{l}\text { Flock size } \\
\text { Small }(\leq 200)\end{array}$ & 1.0 (ref.) & \\
Large $(>200)$ & $0.8(0.4-1.5)$ & 0.449 \\
\hline Introductions of new goats to the flock & 1.0 (ref.) & \\
$\quad$ No & $1.9(1.2-3.0)$ & 0.004 \\
$\quad$ Yes & 1.0 (ref.) & \\
\hline Farm hygiene & $0.3(0.2-0.7)$ & 0.002 \\
$\quad$ Bad & & \\
Good &
\end{tabular}

${ }^{1}$ OR: odds ratio; CI: confidence interval.

For sheep flocks, four factors were retained as being significantly associated with C. abortus seropositivity in the final multivariable logistic regression model. In addition to the flock size which correlated with introduction of new animals to the flock (0.77), open breeding system (0.78), and lower hygienic scores $(-0.38)$. Results showed that farms that introduced new sheep in their flocks had significantly higher odds $(\mathrm{OR}=2.6$; 95\% CI: 1.5-4.4) of being seropositive than farms that did not purchase any animals. The odds of being C. abortus seropositive is two times (OR $=1.8 ; 95 \%$ CI: $1.0-3.4)$ higher in open flocks than closed ones. Additionally, flocks allowing females in $(\mathrm{OR}=1.9 ; 95 \% \mathrm{CI}$ : 1.1-3.3) or females out ( $\mathrm{OR}=2.2 ; 95 \% \mathrm{CI}$ : 1.1-4.3) were at higher risk of $C$. abortus seropositivity compared to flocks did not allow female in or out. On the other hand, sheep age $1.4-2.8$ years had a higher risk $(\mathrm{OR}=1.9 ; 95 \% \mathrm{CI}$ : $1.3-2.9)$ than younger ones $(<1.4$ years). The Pearson's chi-square $(P=0.75)$ and the Hosmer-Lemeshow $(P=0.80)$ fit statistics suggested a reasonable fit of the model.

For goat flocks, two factors were retained as being significantly associated with C. abortus seropositivity in the final multivariable logistic regression model. The odds of C. abortus seropositivity were higher for flocks introducing/purchased new goats ( $\mathrm{OR}=1.9$; $95 \%$ CI: 1.2-3.0) than flocks that did not introduce new animals to flocks. However, results showed that flocks with bad hygienic measures were three times $(\mathrm{OR}=3.0 ; 95 \% \mathrm{CI}$ : 1.5-6.0) more likely to be seropositive for $C$. abortus compared to flocks with good hygienic measures. The Pearson's chi-square $(P=0.4)$ and the Hosmer-Lemeshow $(P=0.9)$ fit statistics suggested a reasonable fit of the model.

\subsection{Molecular Identification of C. abortus}

Vaginal swabs and aborted tissue samples were collected from 17 (81\%) and $11(78.6 \%)$ out of 21 and 14 sheep and goat flocks, respectively. C. abortus pmp gene was identified in $45(93.8 \%)$ and $15(100 \%)$ of samples collected from sheep and goats, respectively (Table 4$)$. 
Table 4. Number of Chlamydia abortus PCR positive vaginal swabs and aborted tissue samples collected from sheep and goats flocks with recent history of abortion.

\begin{tabular}{|c|c|c|c|c|c|c|c|c|c|c|c|}
\hline \multicolumn{6}{|c|}{ No. of Sheep } & \multicolumn{6}{|c|}{ No. of Goats } \\
\hline $\begin{array}{c}\text { Flock } \\
\text { ID }\end{array}$ & Tested & $\begin{array}{c}\text { Sero- } \\
\text { Positive }\end{array}$ & $\begin{array}{c}\text { Recent } \\
\text { Abor- } \\
\text { tion }\end{array}$ & $\begin{array}{c}\text { Vaginal, } \\
\text { Aborted } \\
\text { Tissue } \\
\text { Samples }\end{array}$ & $\begin{array}{l}\text { PCR } \\
\text { Posi- } \\
\text { tive }\end{array}$ & $\begin{array}{l}\text { Flock } \\
\text { ID }\end{array}$ & Tested & $\begin{array}{c}\text { Sero- } \\
\text { Positive }\end{array}$ & $\begin{array}{c}\text { Recent } \\
\text { Abor- } \\
\text { tion }\end{array}$ & $\begin{array}{c}\text { Vaginal, } \\
\text { Aborted } \\
\text { Tissue } \\
\text { Samples }\end{array}$ & $\begin{array}{c}\text { PCR } \\
\text { Posi- } \\
\text { tive }\end{array}$ \\
\hline 1 & 31 & 1 & 0 & 0 & 0 & 1 & 31 & 2 & 0 & 0 & 0 \\
\hline 2 & 37 & 2 & 1 & 1 & 1 & 2 & 38 & 1 & 0 & 0 & 0 \\
\hline 3 & 36 & 1 & 0 & 0 & 0 & 3 & 51 & 2 & 0 & 0 & 0 \\
\hline 4 & 42 & 2 & 2 & 2 & 2 & 4 & 58 & 1 & 1 & 1 & 1 \\
\hline 5 & 50 & 2 & 2 & 2 & 1 & 5 & 72 & 7 & 2 & 1 & 1 \\
\hline 6 & 58 & 1 & 0 & 0 & 0 & 6 & 78 & 9 & 3 & 2 & 2 \\
\hline 7 & 75 & 7 & 75 & 3 & 2 & 7 & 82 & 2 & 1 & 1 & 1 \\
\hline 8 & 83 & 10 & 5 & 3 & 2 & 8 & 89 & 5 & 1 & 1 & 1 \\
\hline 9 & 82 & 12 & 7 & 4 & 4 & 9 & 92 & 15 & 3 & 2 & 2 \\
\hline 10 & 80 & 3 & 0 & 0 & 0 & 10 & 95 & 10 & 2 & 1 & 1 \\
\hline 11 & 85 & 4 & 1 & 1 & 1 & 11 & 99 & 8 & 1 & 1 & 1 \\
\hline 12 & 91 & 10 & 2 & 2 & 2 & 12 & 103 & 18 & 3 & 1 & 1 \\
\hline 13 & 91 & 3 & 1 & 1 & 1 & 13 & 103 & 13 & 4 & 2 & 2 \\
\hline 14 & 99 & 19 & 9 & 4 & 4 & 14 & 110 & 21 & 5 & 2 & 2 \\
\hline 15 & 100 & 11 & 5 & 3 & 3 & & & & & & \\
\hline 16 & 100 & 8 & 99 & 3 & 3 & & & & & & \\
\hline 17 & 113 & 25 & 10 & 6 & 6 & & & & & & \\
\hline 18 & 113 & 9 & 3 & 1 & 1 & & & & & & \\
\hline 19 & 115 & 14 & 8 & 5 & 5 & & & & & & \\
\hline 20 & 116 & 16 & 9 & 4 & 4 & & & & & & \\
\hline 21 & 120 & 27 & 8 & 3 & 3 & & & & & & \\
\hline Total & 1717 & 187 & 247 & 48 & 45 & Total & 1101 & 114 & 26 & 15 & 15 \\
\hline
\end{tabular}

\section{Discussion}

\subsection{Seroprevalence of C. abortus}

In this study, the true seroprevalence of $C$. abortus antibodies at sheep-level was $11.1 \%$, which was higher than the 7.5\% reported previously in sheep in Riyadh, Saudi Arabia; similar to the $10.6 \%$ reported in sheep in India; but lower than the $40.1 \%$ and $24.5 \%$ reported in sheep in China and Algeria, respectively. The true seroprevalence at goat-level in this study was $10.4 \%$, which was similar to the $11.4 \%$ reported in Jordan and lower than the $34.5 \%$ reported in Saudi Arabia and 33\% reported in goats in Spain [19].

Our results revealed that $100 \%$ of the sheep and goat flocks had at least one C. abortus seropositive. This flock-level seroprevalence was similar to the $100 \%$ reported in both sheep and goat flocks in Jordan but was higher than the $70.4 \%$ of sheep flocks in Algeria and $78.6 \%$ of goat flocks in China [29]. The average within sheep and goat flock seroprevalences in this study were $9.6 \%$ (ranging: 1.8 to 22.9 ) and $9.3 \%$ (ranging: 1.8 to 19.5), respectively, indicating the spread of C. abortus infection within sheep and goat flocks in Eastern Saudi Arabia. This result was similar to the range of within flock seroprevalence $3.7 \%$ to $25.0 \%$ reported in sheep in Costa Rica [30] and the $0.0 \%$ to $29.9 \%$ reported in goats in China [29]. Such variation in C. abortus seroprevalence is likely due to differences in sheep and goat breeds, husbandry practices, sanitation, time of sampling, and serological test used. In addition, other reasons for the variations of seroprevalence may be related to differences in climate conditions, including temperature, rainfall, and altitude [31]. However, this study showed no significant differences in the seroprevalence of $C$. abortus antibodies between sheep and goats at the animal- and flock-level. This may attribute to the pasture restriction in the study area, which allows sheep and goat flocks to graze in a common pasture. Previous studies have reported that grazing on contaminated pasture is a source of C. abortus transmission among animals [6,32]. 
In Saudi Arabia, vaccination against chlamydiosis is not applicable. Thus, the relatively high seroprevalence of $C$. abortus in the current study is suspected and could be explained by the fact that the study area (Eastern Province) has borders with five C. abortus endemic countries [33-35]. Furthermore, sheep and goat flocks are seminomadic and moving for long distances every day during the grazing season, which might contribute to the horizontal spread of $C$. abortus to a large number of flocks.

\subsection{Risk Factors}

Various risk factors were assessed to be associated with the seroprevalence of C. abortus in sheep and goat flocks in Saudi Arabia. In the present study, the highest sheep flock $(22.9 \%)$ and goat flock (19.5\%) seroprevalence was reported in large size flocks (>200), which was confirmed by the univariable analysis. This finding is consistent with previous studies from Tunisia and Spain, which indicated that larger size flocks are associated with higher C. abortus seropositivity compared to smaller size flocks. In contrast, other studies from Iran, Algeria, and Brazil [17] have reported no association between flock size and C. abortus seropositivity. The possible explanation that sheep/goats overcrowding in large size flocks may influence animal welfare and hygienic measures, which increase the risk of C. abortus transmission [4,6]. In addition, the association between a higher C. abortus seropositivity and the increased flock size may also be related to the larger number of visitors to the farms by veterinarians, feed suppliers, and farm workers [14,36]. In this study, larger size flocks were correlated with introduction of new animals to the flock (0.77), open breeding system (0.78), and lower hygienic scores $(-0.38)$.

Climates play a role in C. abortus infection [31]. The warm and humid conditions are favorable for the survival of Chlamydia [37]. In the present study, the seroprevalence of C. abortus in winter was significantly higher in sheep and goat flocks than in summer. This result may be due to the climate of Eastern Province is desert which mainly dried hot in summer and mild humid in winter. Similarly, previous studies have reported that season/climate is a risk factor for C. abortus infection in sheep [38] and goat [29] flocks in China.

Several studies have pointed out that the seroprevalence of C. abortus in small ruminants varies based on the management system operated on the flock $[19,39,40]$. Therefore, we could assume that the flock management practices in Saudi Arabia play a significant role in the C. abortus seroprevalence reported in the present study. The univariable risk factor analysis of the flock management revealed several factors to be significantly associated with C. abortus seroprevalence. In sheep flocks, results revealed that flocks with a recent history of abortion, history of treatment, introduced new sheep to the flock, exchanged rams during breeding were identified as risk factors for C. abortus infection. However, in goat flocks, only the goat age, introduction of new goats to flock, and goat exchange during breeding were identified as risk factors for C. abortus infection. Furthermore, it was revealed that the seroprevalence of $C$. abortus in the present study significantly decreases in sheep and goat flocks, where good hygienic measures were applied. Similar results were previously reported in sheep flocks in China [38], Egypt, Algeria, Brazil, Costa Rican, and goat flocks in China [29]. In contrast, a recent study in Tunisian sheep flocks has reported no association between seroprevalence of $C$. abortus and the number of ewes with abortion history, the exchange of breeding male, and the frequency of disinfection [15].

The risk of sheep and goat flocks acquiring C. abortus infection seems to be complex. The multivariable analysis in the present study confirmed that four different variables were associated with $C$. abortus seropositivity in sheep flocks. The multivariable model showed that flocks using open breeding system, adding new sheep and exchanging sheep during breeding are at higher risk of C. abortus seropositivity. Similar to our results, Mamlouk et al. reported that the absence of previous control of sheep, when introduced to the flock, is a risk for C. abortus seropositivity. Furthermore, Barkallah et al. observed that quarantine had a significant relation with C. abortus infection in sheep. The observed high seroprevalence of $C$. abortus in older sheep in this study was in agreement with previous 
studies, which reported an association between the increase of $C$. abortus seroprevalence and sheep age $[41,42]$. This result may be due to earlier infection or the high chance of exposure to the source of infection with age increase [38].

In goat flocks, results showed a significant relationship between C. abortus seropositivity and the introduction of new goats to the flock. Some farms purchased new goats without pre-testing and history taking, leading to an increased risk of infection. This result is consistent with Santos et al. [17], who reported that sharing goats for breeding between farms contributed to the spread of $C$. abortus infection from one flock to another. On the other hand, the risk of $C$. abortus seropositivity in goat flocks with good hygienic measures is lower than flocks with bad hygienic measures, which contrasts with Santos et al., who reported no association between use of disinfectant and risk of $C$. abortus seropositivity.

\subsection{Study Limitations}

The ELISA test was used in the present study to assess the seroprevalence of $C$. abortus antibodies in sheep and goat serum samples. Although the sensitivity and specificity of the used ELISA are high but indeed not $100 \%$, so some misclassification errors may therefore occur, which may add some noise to the observed relationship between dependent and independent variables. Furthermore, the antigenic cross-reactivity between C. abortus and C. pecorum in sheep may result in an overestimation of seroprevalence $[43,44]$. Because of the relatively small number of goat flocks included in the study, only variables that were strongly associated with C. abortus could be evaluated in the final model. The absence of a particular variable from the final model may be due to the limited sample size. However, the identification of at least one PCR positive animal in each flock decreases the impact of these limitations on this study results.

\section{Materials and Methods}

\subsection{Study Area}

Eastern Province $\left(22^{\circ} 30^{\prime} \mathrm{N}, 51^{\circ} 00^{\prime} \mathrm{E}\right)$ is located in the eastern side of Saudi Arabia, at $390 \mathrm{~km}$ from the capital Riyadh and shares the borders with five countries, including Oman, United Arab Emirates, Qatar, Kuwait, and Iraq (Figure 3). The Eastern Province is the third most populated province in Saudi Arabia, with diverse climatic conditions ranging from semi-desert to desert. According to the General Authority for Statistics for 2015, sheep and goat populations in Eastern Province represent 13\% and 2.5\% of the total sheep and goat populations in the kingdom.

The production system of small ruminants is mainly of the seminomadic type as sheep and goats move out from their raising farms for grazing during early March until August when pastures are mostly available. During the fall and winter months, sheep and goats are housed and fed on concentrates. Sheep and goats in Saudi Arabia are mainly raised for meat production.

\subsection{Study Design}

A cross-sectional study with a two-stage sampling process was carried during 2015-2016. The total number of sheep and goat flocks to be sampled was determined using the 'epi.ssclus2estb' function of the 'epiR' package with $50 \%$ an expected seroprevalence, $5 \%$ absolute precision, and $95 \%$ confidence interval (CI). The required number of flocks was determined to be 12 flocks. For the sheep population, the number of flocks was increased to 21 , and for the goat population increased to 14 flocks to improve the precision of the estimated seroprevalence in sheep and goats [45]. Selected sheep flocks size ranged from 40 to 800 (median $=350$ ) sheep per flock. However, selected goat flocks size ranged from 40 to 500 (median $=290$ ) goats per flock. The number of sheep and goats sampled per flock was calculated according to Cannon and Roe, using an expected seroprevalence of $8 \%$ with a $95 \%$ CI to detect at least one seropositive. 


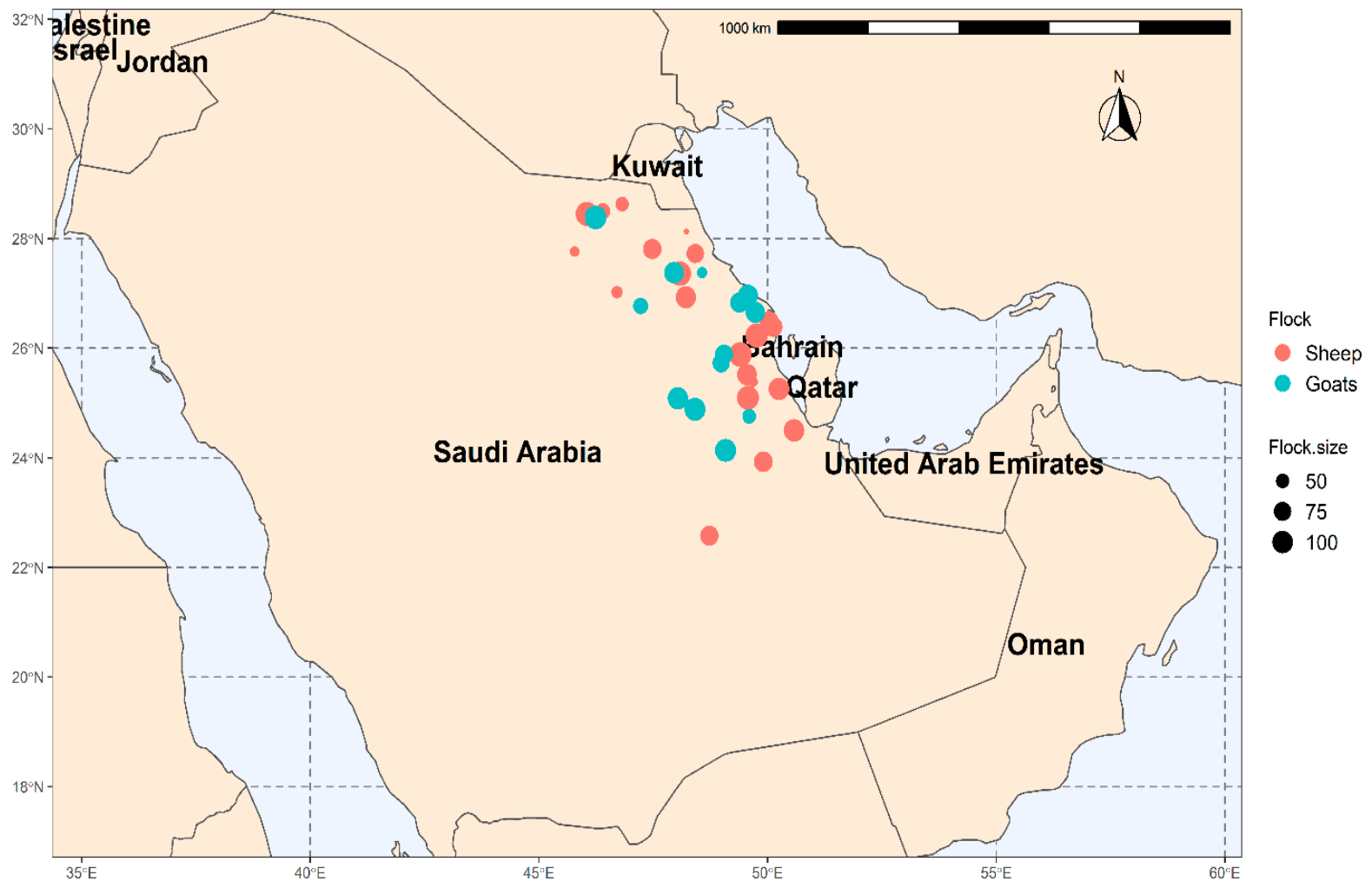

Figure 3. Map of Saudi Arabia showed the locations of sampled sheep and goat flocks.

\subsection{Sample and Data Collection}

A two-stage random sampling process was carried out. Flocks were selected in the first stage and animals within flocks were selected in the second stage. In total, blood samples were collected from 1717 sheep in 21 flocks and 1101 goats in 14 flocks, with an average of 80 animals sampled per flock. In addition, vaginal swabs and aborted tissue samples were collected from a number of sheep $(n=48)$ and goats $(n=15)$ with recent history of abortion. All samples were labeled with flock and animal ID and sampling dates and then transported to the laboratory for serological analysis.

A questionnaire was constructed to collect information about flock management and animal risk factors possibly associated with $C$. abortus infection in sheep and goats. The questionnaire consisted of 11 closed and open-ended questions written in Arabic and available from the corresponding author upon request. The questionnaire was completed by face-to-face interviews with the flock owner on the day of sampling. Questions covered the flock characteristics and management practices, including flock size (small ( $\leq 200$ animal/flock) and large (>200 animal/flock)), the season of sampling, the recent history of abortion (Yes and No), the introduction of new animals to flock (Yes and No), mixed breeding (Yes and No), farm hygiene (Bad and Good), history of previous treatment (Yes and No), type of breeding system (Open and Closed), animal exchange during breeding (No, Female in and out), and type of the used vaccine. In addition to the animal age, sex, and breed, this information is presented in Supplementary Table S1.

\subsection{Serological Examination}

Serum samples were tested for antibodies against $C$. abortus infection using commercial indirect ELISA kits (IDEXX Chlamydiosis Total Ab Test, IDEXX Laboratories, Broomfield, CO, USA) according to manufacture instructions. Briefly, serum samples and controls were diluted at 1:400 and then tested in duplicates. Microplate ELISA reader measured the optical densities (OD) at $450 \mathrm{~nm}$. The average OD was estimated for duplicate samples and controls, then used to calculate the OD $\%$ by the following equation: 


$$
\mathrm{OD}(\%)=(\mathrm{OD} \text { sample }-\mathrm{OD} \text { negative control }) /(\mathrm{OD} \text { positive control }-\mathrm{OD} \text { negative control }) \times 100 \text {. }
$$

Any sample with OD\% $>40 \%$ was considered seropositive; if the OD\% was between $\geq 30$ and $\leq 40$, the result was considered doubtful, while any sample with an OD $\%<30 \%$ was classified as seronegative. Regarding the diagnostic performance of the IDEXX ELISA's kites used in this study, Wilson et al. [46] evaluated the accuracy of ELISA in the absence of a gold standard and reported a $98.1 \%$ sensitivity (Se) and $100 \%$ specificity (Sp) in sheep and goats.

\subsection{Molecular Identification of C. abortus}

DNA was extracted from vaginal swabs and aborted tissue samples using the Qiagen QIAamp DNA mini kit (Qiagen, Courtaboeuf, France) according to the manufacturer's instructions. Purified DNA was amplified by PCR for detection of the pmp gene of $C$. abortus using the primer (CpsiA (5'-ATGAAACATCCAGTCTACTGG-3') and CpsiB (5'TTGTGTAGTAATATTATCAAA-3')) previously described by Greco et al. [47]. Briefly, $2 \mu \mathrm{L}$ sample of each purified genomic DNAs was amplified in $20 \mu \mathrm{L}$ of the final volume of a 2X HotStartTaq Plus Master Mix (QIAGEN, Germantown, MD, USA) containing $1.5 \mathrm{mM}$ $\mathrm{MgCl} 2,200 \mu \mathrm{M}$ of each dNTP,1-unit HotStartTaq Plus DNA polymerase, and $10 \mu \mathrm{M}$ of each forward and reverse primers. The PCR assay was performed using DNA thermal cycler I (BIORAD, CA, USA) according to Greco et al. [47]. The amplified PCR products were electrophoresed in $1.5 \%$ agarose gel stained with ethidium bromide and documented using an ultraviolet gel documentation system (BIO-RAD, Hercules, CA, USA).

\subsection{Statistical Analysis}

Epidemiological data and results of the serological analysis were introduced into Stata Statistical Software v. 15 (Stata Corp, College Station, TX, USA) and R software (R Core Team, 2019; version 3.5.3) for descriptive and statistical data analysis with results considered significant at $P$-value $<0.05$. The apparent seroprevalence of $C$. abortus at the individual animal-level was estimated as the ratio of seropositive sheep/goat to the total number of sheep/goats examined. However, the true seroprevalence of $C$. abortus at the animal-level was estimated according to Thrusfield [48] using the 'epi.pro' function from the 'epiR' package in $\mathrm{R}$ [49]. The flock-level seroprevalence was estimated from the ratio of positive flocks to the total number of flocks tested. Flocks that contain at least one seropositive sheep/goat were considered positive. The flock seroprevalence was adjusted for Se and Sp of ELISA test used in the study to obtain the true flock seroprevalence using the following formula [50]:

$$
\mathrm{THP}=(\mathrm{AHP}+\mathrm{HSp}-1) /(\mathrm{HSe}+\mathrm{HSp}-1),
$$

where THP and AHP are the true and apparent flock seroprevalence, respectively. HSe and HSp refer to the flock-test sensitivity and specificity, respectively, based on animal-test results, calculated using 'epi.herdtest' function from Package 'epiR'.

Analysis of the risk factors potentially associated with C. abortus seropositivity was evaluated in two steps, using univariable and multivariable logistic regression models. Firstly, univariable screening of all risk factors for association with $C$. abortus seropositivity at liberal $P$-value $<0.20$ using unconditional associations. Significant variables in the univariable analysis were checked for collinearity using Spearman correlation coefficients and were considered collinear when coefficient $>0.8$ [51]. Retained variables were used to conduct multivariable analysis, and non-significant variables were removed sequentially using backward elimination at $P$-value $<0.05$. The fit of the final model was evaluated using Hosmer-Lemeshow goodness-of-fit statistics [52]. 


\section{Conclusions}

The present study revealed that $C$. abortus seroprevalence in sheep $(11.1 \%)$ and goats $(10.4 \%)$ is relatively high in Eastern Province, Saudi Arabia. Consequently, some management practices must be implemented, especially the risk factors identified in this work, such as introducing new animals to the flock and improving farm hygienic measures. Since C. abortus is a zoonotic disease that can cause health and economic loss in humans and livestock, thus the use of a chlamydial vaccine is strongly recommended. In addition to the implementation of integrated control and efficient management measures to prevent and control C. abortus infection in sheep and goats in Eastern Province, Saudi Arabia, it also could be used to reduce the risk of C. abortus infection in sheep and goat flocks with similar management practices in other regions.

Supplementary Materials: The following are available online at https://www.mdpi.com/article/10 $.3390 /$ pathogens $10040489 / \mathrm{s} 1$.

Author Contributions: Conceptualization, M.F., A.E. and I.E.; methodology, M.F., A.E. and I.E.; software, A.E. and I.E.; validation, M.F., A.E. and I.E.; formal analysis, A.E. and I.E.; investigation, M.A. (Mohammed Alorabi), I.Q. and T.A.-M.; resources, M.A. (Mohammed Alorabi), I.Q. and T.A.-M.; data curation, M.A. (Mohammed Alorabi), I.Q. and T.A.-M.; writing-original draft preparation, M.F., A.E. and I.E.; writing — review and editing, M.F., A.E. and I.E.; visualization, A.E. and I.E; supervision, M.F.; project administration, M.A. (Mohamed Alkafafy); funding acquisition, M.A. (Mohamed Alkafafy). All authors have read and agreed to the published version of the manuscript.

Funding: Taif University Researchers Supporting Project number (TURSP-2020/57), Taif University, P.O. Box 11099, Taif 21944, Saudi Arabia.

Institutional Review Board Statement: The Taif University Ethics Committee has approved the study protocol (TURSP-2020-57).

Informed Consent Statement: Not applicable.

Data Availability Statement: The data presented in this study are available on request from the corresponding author.

Acknowledgments: Authors thank also Taif University Researchers Sup-porting Program (Project number: TURSP-2020/57), Taif University, Saudi Arabia for their support.

Conflicts of Interest: The authors declare no conflict of interest.

\section{References}

1. Everett, K.D. Chlamydia and Chlamydiales: More than meets the eye. Vet. Microbiol. 2000, 75, 109-126. [CrossRef]

2. Essig, A.; Longbottom, D. Chlamydia abortus: New aspects of infectious abortion in sheep and potential risk for pregnant women. Curr. Clin. Microbiol. Rep. 2015, 2, 22-34. [CrossRef]

3. Longbottom, D.; Coulter, L. Animal chlamydioses and zoonotic implications. J. Comp. Pathol. 2003, 128, 217-244. [CrossRef] [PubMed]

4. Lenzko, H.; Moog, U.; Henning, K.; Lederbach, R.; Diller, R.; Menge, C.; Sachse, K.; Sprague, L.D. High frequency of chlamydial co-infections in clinically healthy sheep flocks. BMC Vet. Res. 2011, 7, 1-13. [CrossRef] [PubMed]

5. Wang, F.-I.; Shieh, H.; Liao, Y.-K. Prevalence of Chlamydophila abortus infection in domesticated ruminants in Taiwan. J. Vet. Med. Sci. 2001, 63, 1215-1220. [CrossRef] [PubMed]

6. Longbottom, D.; Livingstone, M.; Maley, S.; van der Zon, A.; Rocchi, M.; Wilson, K.; Wheelhouse, N.; Dagleish, M.; Aitchison, K.; Wattegedera, S. Intranasal infection with Chlamydia abortus induces dose-dependent latency and abortion in sheep. PLoS ONE 2013, 8, e57950. [CrossRef] [PubMed]

7. Aitken, I.; Longbottom, D. Chlamydial abortion. Dis. Sheep 2007, 4, 105-112.

8. Shewen, P.E. Chlamydial infection in animals: A review. Can. Vet. J. 1980, 21, 2.

9. Deutz, A.; Fuchs, K.; Schuller, W.; Nowotny, N.; Auer, H.; Aspöck, H.; Stünzner, D.; Kerbl, U.; Klement, C.; Köfer, J. Seroepidemiological studies of zoonotic infections in hunters in southeastern Austria-prevalences, risk factors, and preventive methods. Berl. Munch. Tierarztl. Wochenschr. 2003, 116, 306-311.

10. Pospischil, A.; Thoma, R.; Hilbe, M.; Grest, P. Abortion in woman caused by caprine Chlamydophila abortus (Chlamydia psittaci serovar 1). Swiss Med Wkly. 2002, 132, 64-66. 
11. Meijer, A.; Brandenburg, A.; De Vries, J.; Beentjes, J.; Roholl, P.; Dercksen, D. Chlamydophila abortus infection in a pregnant woman associated with indirect contact with infected goats. Eur. J. Clin. Microbiol. Infect. Dis. 2004, 23, 487-490. [CrossRef] [PubMed]

12. Walder, G.; Hotzel, H.; Brezinka, C.; Gritsch, W.; Tauber, R.; Würzner, R.; Ploner, F. An unusual cause of sepsis during pregnancy: Recognizing infection with Chlamydophila abortus. Obstet. Gynecol. 2005, 106, 1215-1217. [CrossRef] [PubMed]

13. Rohde, G.; Straube, E.; Essig, A.; Reinhold, P.; Sachse, K. Chlamydial zoonoses. Dtsch. Arztebl. Int. 2010, 107, 174. [CrossRef] [PubMed]

14. Hireche, S.; Ababneh, M.M.K.; Bouaziz, O.; Boussena, S. Seroprevalence and molecular characterization of Chlamydia abortus in frozen fetal and placental tissues of aborting ewes in northeastern Algeria. Trop. Anim. Health Prod. 2016, 48, 255-262. [CrossRef]

15. Mamlouk, A.; Guesmi, K.; Ouertani, I.; Kalthoum, S.; Selmi, R.; Aicha, E.B.; Mohamed, B.B.H.; Gharbi, R.; Lachtar, M.; Dhaouadi, A. Seroprevalence and associated risk factors of Chlamydia abortus infection in ewes in Tunisia. Comp. Immunol. Microbiol. Infect. Dis. 2020, 71, 101500. [CrossRef]

16. Selim, A.; Manaa, E.A.; Waheed, R.M.; Alanazi, A.D. Seroprevalence, associated risk factors analysis and first molecular characterization of chlamydia abortus among Egyptian sheep. Comp. Immunol. Microbiol. Infect. Dis. 2021, 74, 101600. [CrossRef]

17. Santos, C.S.; Piatti, R.M.; Azevedo, S.S.; Alves, C.J.; Higino, S.S.; Silva, M.L.; Brasil, A.W.; Gennari, S.M. Seroprevalence and risk factors associated with Chlamydophila abortus infection in dairy goats in the Northeast of Brazil. Pesqui. Veterinária Bras. 2012, 32, 1082-1086. [CrossRef]

18. Leopoldo, T.B.; Pinheiro, R.R.; Alves, F.; Porfirio, K.d.P.; do Rêgo, W.; Diniz, B.; Cardoso, J.; Paula, N.d.O. Risk factors in the transmission and seroprevalence of Chlamydophila abortus infection in sheep and goats. Pesqui. Agropecuária Bras. 2016, 51, 654-660. [CrossRef]

19. Tejedor-Junco, M.T.; González-Martín, M.; Corbera, J.A.; Santana, Á.; Hernández, C.N.; Gutiérrez, C. Preliminary evidence of the seroprevalence and risk factors associated with Chlamydia abortus infection in goats on the Canary Islands, Spain. Trop. Anim. Health Prod. 2019, 51, 257-260. [CrossRef]

20. Borujeni, M.P.; Bakhtiari, N.M.; Hajikolaei, M.H.; Mousavi, M. Chlamydia abortus infection in goats in the southwest of Iran. Rev. Méd. Vét. 2019, 170, 9-14.

21. Benaissa, M.H.; Mimoune, N.; Youngs, C.R.; Kaidi, R.; Faye, B. First report of Chlamydophila abortus infection in the dromedary camel (Camelus dromedarius) population in eastern Algeria. Comp. Immunol. Microbiol. Infect. Dis. 2020, 73, 101557. [CrossRef]

22. Talafha, A.Q.; Ababneh, M.M.; Ababneh, M.M.; Al-Majali, A.M. Prevalence and risk factors associated with Chlamydophila abortus infection in dairy herds in Jordan. Trop. Anim. Health Prod. 2012, 44, 1841-1846. [CrossRef]

23. Sachse, K.; Hotzel, H.; Slickers, P.; Ellinger, T.; Ehricht, R. DNA microarray-based detection and identification of Chlamydia and Chlamydophila spp. Mol. Cell. Probes 2005, 19, 41-50. [CrossRef]

24. Rodolakis, A.; Mohamad, K.Y. Zoonotic potential of Chlamydophila. Vet. Microbiol. 2010, 140, 382-391. [CrossRef] [PubMed]

25. Travniček, M.; Kováčová, D.; Bhide, M.; Zubrický, P.; Čisláková, L. Detection of IgG antibodies against Chlamydophila abortus in sheep with reproductive disorders. Acta Vet. Brno 2003, 72, 95-99. [CrossRef]

26. Hussein, M.F.; Alshaikh, M.; Gad El-Rab, M.; Aljumaah, R.; Gar El Nabi, A.; Abdel Bagi, A. Serological prevalence of Q fever and chlamydiosis in camels in Saudi Arabia. J. Anim. Vet Adv. 2008, 7, 685-688.

27. Al Khalifa, I.; Alshaikh, M.; Aljumaah, R.; Jarelnabi, A.; Hussein, M.F. Serological prevalence of abortifacient agents in female Mijaheem camels (Camelus dromedarius) in Saudi Arabia. J. Anim. Res. 2018, 8, 335-343. [CrossRef]

28. Aljumaah, R.S.; Hussein, M.F. Serological prevalence of ovine and caprine chlamydophilosis in Riyadh region, Saudi Arabia. Afr. J. Microbiol. Res. 2012, 6, 2654-2658.

29. Hu, S.-F.; Li, F.; Zheng, W.-B.; Liu, G.-H. Seroprevalence and risk factors of Chlamydia abortus infection in goats in Hunan province, subtropical China. Vector Borne Zoonotic Dis. 2018, 18, 500-503. [CrossRef] [PubMed]

30. Villagra-Blanco, R.; Dolz, G.; Montero-Caballero, D.; Romero-Zúñiga, J.J. Detection of antibodies against Chlamydophila abortus in Costa Rican sheep flocks. Open Vet. J. 2015, 5, 122-126.

31. Qin, S.-Y.; Huang, S.-Y.; Yin, M.-Y.; Tan, Q.-D.; Liu, G.-X.; Zhou, D.-H.; Zhu, X.-Q.; Zhou, J.-Z.; Qian, A.-D. Seroprevalence and risk factors of Chlamydia abortus infection in free-ranging white yaks in China. BMC Vet. Res. 2015, 11, 1-5. [CrossRef] [PubMed]

32. Wilsmore, A.; Parsons, V.; Dawson, M. Experiments to demonstrate routes of transmission of ovine enzootic abortion. Br. Vet. J. 1984, 140, 380-391. [CrossRef]

33. Fahad, O.A.; Salman, S.S. Survey for ovine and caprine chlamydiosis by ELISA in AL-Fallujah city/Iraq. J. Entomol. Zool. Stud. 2017, 5, 322-326.

34. Zaher, H.A.; Swelum, A.A.-A.; Alsharifi, S.A.; Alkablawy, A.H.; Ismael, A.B. Seroprevalence of chlamydiosis in Abu Dhabi dromedary camel (Camelus dromedarius) and its association with hematobiochemical responses towards the infection. J. Adv. Vet. Anim. Res. 2017, 4, 175-180. [CrossRef]

35. Salman, S.S.; Mahmood, A.K.; Mosa, S.T. Seroprevalence of brucellosis in sheep with or without chlamydiosis in Iraq. Online J. Vet. Res. 2018, 22, 615-618.

36. Al-Qudah, K.; Sharif, L.; Raouf, R.; Hailat, N.; Al-Domy, F. Seroprevalence of antibodies to Chlamydophila abortus shown in Awassi sheep and local goats in Jordan. Vet. Med. UZPI 2004, 49, 460. [CrossRef]

37. Sun, L.-X.; Liang, Q.-L.; Hu, X.-H.; Li, Z.; Yang, J.-F.; Zou, F.-C.; Zhu, X.-Q. First report of chlamydia seroprevalence and risk factors in domestic black-boned sheep and goats in China. Front. Vet. Sci. 2020, 7, 363. [CrossRef] 
38. Qin, S.-Y.; Yin, M.-Y.; Cong, W.; Zhou, D.-H.; Zhang, X.-X.; Zhao, Q.; Zhu, X.-Q.; Zhou, J.-Z.; Qian, A.-D. Seroprevalence and risk factors of Chlamydia abortus infection in Tibetan sheep in Gansu province, northwest China. Sci. World J. 2014, $2014,193464$. [CrossRef]

39. Campos-Hernández, E.; Vázquez-Chagoyán, J.C.; Salem, A.Z.; Saltijeral-Oaxaca, J.A.; Escalante-Ochoa, C.; López-Heydeck, S.M.; de Oca-Jiménez, R.M. Prevalence and molecular identification of Chlamydia abortus in commercial dairy goat farms in a hot region in Mexico. Trop. Anim. Health Prod. 2014, 46, 919-924. [CrossRef]

40. Esmaeili, H.; Bolourchi, M.; Mokhber-Dezfouli, M.R.; Teimourpour, A. Detection of Chlamydia abortus and risk factors for infection in small ruminants in Iran. Small Rumin. Res. 2021, 197, 106339. [CrossRef]

41. Hireche, S.; Bouaziz, O.; Djenna, D.; Boussena, S.; Aimeur, R.; Kabouia, R.; Bererhi, E.H. Seroprevalence and risk factors associated with Chlamydophila spp. infection in ewes in the northeast of Algeria. Trop. Anim. Health Prod. 2014, 46, 467-473. [CrossRef]

42. Esmaeili, H.; Bolourchi, M.; Mokhber-Dezfouli, M.R. Seroprevalence of Chlamydia abortus infection in sheep and goats in Iran. Iran. J. Vet. Med. 2015, 9, 73-77.

43. Longbottom, D.; Fairley, S.; Chapman, S.; Psarrou, E.; Vretou, E.; Livingstone, M. Serological diagnosis of ovine enzootic abortion by enzyme-linked immunosorbent assay with a recombinant protein fragment of the polymorphic outer membrane protein POMP90 of Chlamydophila abortus. J. Clin. Microbiol. 2002, 40, 4235-4243. [CrossRef]

44. McCauley, L.; Lancaster, M.; Butler, K.; Ainsworth, C. Serological analysis of Chlamydophila abortus in Australian sheep and implications for the rejection of breeder sheep for export. Aust. Vet. J. 2010, 88, 32-38. [CrossRef] [PubMed]

45. Binkin, N.; Sullivan, K.; Staehling, N.; Nieburg, P. Rapid nutrition surveys: How many clusters are enough? Disasters 1992, 16, 97-103. [CrossRef] [PubMed]

46. Wilson, K.; Livingstone, M.; Longbottom, D. Comparative evaluation of eight serological assays for diagnosing Chlamydophila abortus infection in sheep. Vet. Microbiol. 2009, 135, 38-45. [CrossRef] [PubMed]

47. Greco, G.; Totaro, M.; Madio, A.; Tarsitano, E.; Fasanella, A.; Lucifora, G.; Buonavoglia, D. Detection of Chlamydophila abortus in sheep and goat flocks in southern Italy by PCR using four different primer sets. Vet. Res. Commun. 2005, 29, 107-115. [CrossRef]

48. Thrusfield, M. Data collection and management. In Veterinary Epidemiology, 3rd ed.; Blackwell Science Ltd.: Oxford, UK, 2007; pp. 188-213.

49. Stevenson, M.; Nunes, T.; Sanchez, J.; Thornton, R.; Reiczigel, J.; Robison-Cox, J.; Sebastiani, P. epiR: An R Package for the Analysis of Epidemiological Data. R Package Version 0.9-43. 2013. Available online: https://CRAN.R-project.org/package=epiR (accessed on 15 July 2020).

50. Christensen, J.; Gardner, I.A. Herd-level interpretation of test results for epidemiologic studies of animal diseases. Prev. Vet. Med. 2000, 45, 83-106. [CrossRef]

51. Mason, C.H.; Perreault, W.D. Collinearity, power, and interpretation of multiple regression analysis. J. Mark. Res. 1991, 28, 268-280. [CrossRef]

52. Dohoo, I.R.; Martin, W.; Stryhn, H.E. Veterinary Epidemiologic Research; University of Prince Edward Island: Charlottetown, PE, Canada, 2003. 